\title{
Late Pleistocene carnivores (Carnivora: Mammalia) from a cave sedimentary deposit in northern Brazil
}

\author{
SHIRLLEY RODRIGUES ${ }^{1,2}$, LEONARDO S. AVILLA ${ }^{2}$, \\ LEOPOLDO H. SOIBELZON ${ }^{3 *}$ and CAMILA BERNARDES ${ }^{2}$ \\ ${ }^{1}$ Museu Nacional-UFRJ, Departamento de Geologia e Paleontologia, Laboratório de Processamento \\ de Imagem Digital, Quinta da Boa Vista, São Cristóvão, 20940-040 Rio de Janeiro, RJ, Brasil \\ ${ }^{2}$ Universidade Federal do Estado do Rio de Janeiro (UNIRIO), Departamento de Zoologia, \\ Laboratório de Mastozoologia, Avenida Pasteur, 458, IBIO, sala 501, Urca, 22240290 Rio de Janeiro, RJ, Brasil \\ ${ }^{3}$ División Paleontología Vertebrados, Museo de La Plata, Paseo del Bosque, 1900 La Plata, Argentina, \\ Consejo Nacional de Investigaciones Científicas y Técnicas
}

Manuscript received on June 25; accepted for publication on July 29, 2014

\begin{abstract}
The Brazilian Quaternary terrestrial Carnivora are represented by the following families: Canidae, Felidae, Ursidae, Procyonidae Mephitidae and Mustelidae. Their recent evolutionary history in South America is associated with the uplift of the Panamanian Isthmus, and which enabled the Great American Biotic Interchange (GABI). Here we present new fossil records of Carnivora found in a cave in Aurora do Tocantins, Tocantins, northern Brazil. A stratigraphical controlled collection in the sedimentary deposit of the studied cave revealed a fossiliferous level where the following Carnivora taxa were present: Panthera onca, Leopardus sp., Galictis cuja, Procyon cancrivorus, Nasua nasua and Arctotherium wingei. Dating by Electron Spinning Resonance indicates that this assemblage was deposited during the Last Glacial Maximum (LGM), at least, 22.000 YBP. The weasel, G. cuja, is currently reported much further south than the record presented here. This may suggest that the environment around the cave was relatively drier during the LGM, with more open vegetation, and more moderate temperatures than the current Brazilian Cerrado.
\end{abstract}

Key words: carnivora, fossil record, Pleistocene, South America.

\section{INTRODUCTION}

The Brazilian Quaternary fossil deposits are mainly represented by karstic caves (Auler et al. 2003). The first studies of fossil mammals found in caves of South America were conducted from 1837 to 1844 by Peter Lund in Lagoa Santa, state of Minas Gerais, southeastern Brazil (Marchesotti 2011). As part of his research, Lund described the first fossil records of Carnivora from Brazil.

Correspondence to: Shirlley Rodrigues

E-mail: shirlleyrodrigues45@hotmail.com

*CONICET
Since Lund, other findings of fossil carnivores have been made in Brazilian fossil deposits of Acre (Ranzi 2000), Bahia (Paula-Couto 1955, 1980, Cartelle and Hartwig 1996), Ceará (Gomide 1989, Gomide et al. 1987), Goiás (Moreira and Melo 1971), Mato Grosso (Cartelle and Hirooka 2005), Mato Grosso do Sul (Salles et al. 1999, Perini et al. 2009), Minas Gerais (Paula-Couto 1955, Cartelle 1994), Paraíba (Bergqvist 1993), Piauí (Guérin 1991), Rio Grande do Norte (Porpino et al. 2004, Araújo-Júnior and Porpino 2011) and Rio Grande do Sul (Rodrigues et al. 2004) 
(see Table I). However, the Quaternary carnivores of central and northern regions of Brazil are still poorly known. Conducting studies in those regions that include numerical dating and stratigraphy are critical to understand the Quaternary evolution of mammals in South America. On this context, we are reporting here new dated records of Quaternary carnivores from a karstic cave at northern Brazil.

\section{ABBREVIATIONS}

I1: upper first incisor; I2: upper second incisor; I3: upper third incisor; $\mathbf{C 1}$ : upper canine; $\mathbf{P 2}$ : upper second premolar; P3: upper third premolar; P4: upper fourth premolar; i1: lower first incisor; i2: lower second incisor; i3: lower third incisor; p1: lower first premolar; p3: lower third premolar; p4: lower fourth premolar; m1: lower first molar; $\mathbf{m} 2$ : lower second molar. UNIRIO-PM: Collection of fossil mammals, Laboratório de Mastozoologia at Universidade Federal do Estado do Rio de Janeiro.

\section{REgional AND GeOlogicAl SETTINGS}

The fossils described here were collected in 2011, 2012 and 2013 in a limestone cave named "Gruta do Urso", at Aurora do Tocantins (-12,583; -46,516), state of Tocantins, northern Brazil. The geology of the studied area is still poorly understood. Online notes of Companhia de Pesquisa de Recursos Minerais (CPRM) report on the studied region, carbonate and terrigenous deposits of the Bambuí Group.

The excavation inside the cave was controlled in order to identify the stratigraphy of the deposit. Three stratigraphic levels were recognized: 1- A superficial carbonated layer that cements the top of the cave deposit; 2- A laminated reddish-grey loess-like sediment with granulometry from very thin to thin, with a thickness of 180 to 220 millimeters. Only the second layer (level 2) contained fóssil remains. 3-A yellowish layer of thicker granulometry and containing several detached angular clasts that originated from the cave walls. This third level presents a thickness of $500 \mathrm{~mm}$ but it may vary according to the different sections of the cave.

\section{MATERIALS AND METHODS}

The material was identified by direct comparisons with specimens housed in the following collections: Museu Nacional/Universidade Federal do Rio de Janeiro, Rio de Janeiro, Brazil (MN/UFRJ); Museu de Ciências Naturais of the Pontifícia Universidade Católica de Minas Gerais, Minas Gerais, Brazil (PUC Minas); Museo de La Plata, Universidad Nacional de La Plata, La Plata, Argentina (MLP); and Museo Argentino de Ciencias Naturales "Bernardino Rivadavia", Buenos Aires, Argentina (MACN). The identification was also based on descriptions found in the literature (Berman 1994, Seymour 1989, 2012, Yensen and Tarifa 2003).

The information on the geographical distribution of extant species was based on Wilson and Mittermeier (2009).

Electron Spinning Resonance (ESR) dating was performed on the specimen UNIRIO-PM 1027 (specimen L4) by the Physics Department of the Universidade de São Paulo (FFCLRP-USP; www. ffclrp.usp.br/departamentos/fisica). We chose to date only one specimen due to the fact that all carnivores were recovered from the same level (level 2). Therefore, this specimen is considered to be synchronic with the remaining specimens described here.

\section{RESULTS}

A total of 25 specimens, described hereafter, were identified within five families and six species of Carnivora (Table I).

The ESR dating of the specimen UNIRIOPM 1027 (Panthera onca) resulted in 22,000 YBP, corresponding to the Lujanian Age (late Pleistocene - early Holocene). Additionally, the recovering of Equus (Amerhippus) neogeus a species that biostratigraphically defines the Lujanian Age (see Cione and Tonni 1999) also from level 2 gives further support to a late Pleistocene - early Holocene Age. 
TABLE I

Fossil and recent species of Carnivora recorded in Brazil. RS-Rio Grande do Sul; PR-Paraná; SP- São Paulo; MGMinas Gerais; MT- Mato Grosso; GO- Goiás; TO- Tocantins; PI-Piauí; BA- Bahia; SE- Sergipe; PB- Paraíba; CECeará; RN- Rio Grande do Norte; AM- Amazonas. Adapted from Cartelle 1999. (*) - Doubtful record.

\begin{tabular}{|c|c|c|c|c|c|c|c|c|c|c|c|c|c|c|c|}
\hline Species & TO & RS & PR & MS & SP & MG & MT & GO & PI & $\mathbf{B A}$ & SE & PB & $\mathbf{C E}$ & $\mathbf{R N}$ & $\mathbf{A M}$ \\
\hline Lycalopex vetulus & & & & & & $\mathrm{x}$ & & & & & & & & & \\
\hline Lycalopex gymnocercus & & & & & & $\mathrm{x}$ & & & & & & & & & \\
\hline Chrysocyon brachyurus & & & & $\mathrm{x}$ & & $\mathrm{x}$ & & & & & & & & & \\
\hline Cerdocyon thous & $\mathrm{x}$ & & & & & $\mathrm{x}$ & $\mathrm{x}$ & $\mathrm{x}$ & $\mathrm{x}$ & $\mathrm{x}$ & & $\mathrm{x}$ & & $\mathrm{x}$ & \\
\hline Theriodictis & & $\mathrm{x}$ & & & & $\mathrm{x}$ & & & & & & & & & \\
\hline Dusicyon avus & & $\mathrm{x}$ & & & & $\mathrm{x}$ & & & & & & & & & \\
\hline Protocyon troglodites & & $\mathrm{x}$ & $\mathrm{x}$ & $\mathrm{x}$ & & & $\mathrm{x}$ & & $\mathrm{x}$ & $\mathrm{x}$ & $\mathrm{x}$ & & $\mathrm{x}$ & $\mathrm{x}$ & \\
\hline Speothos pacivorus & & & & & & $\mathrm{x}$ & & & & & & & & & \\
\hline Speothos venaticus & & & & & & $\mathrm{x}$ & & & & $\mathrm{x}$ & & & & & \\
\hline Arctotherium wingei & $\mathrm{x}$ & $*$ & & & & $\mathrm{x}$ & & & $\mathrm{x}$ & $\mathrm{x}$ & & & $\mathrm{x}$ & $\mathrm{x}$ & \\
\hline Procyon cancrivorus & $\mathrm{x}$ & & & & & $\mathrm{x}$ & & & & $\mathrm{x}$ & & & & & \\
\hline Nasua nasua & $\mathrm{x}$ & & & & & $\mathrm{x}$ & & & & $\mathrm{x}$ & & & & & \\
\hline Eira barbara & & & & & & $\mathrm{x}$ & & $\mathrm{x}$ & & $\mathrm{x}$ & & & & & $*$ \\
\hline Galictis cuja & $\mathrm{x}$ & & & & & & & & & & & & & & \\
\hline Galictis vittata & & & & & & $\mathrm{x}$ & & & & & & & & & \\
\hline Conepatus semistriatus & & & & & & $\mathrm{x}$ & & & & $\mathrm{x}$ & & & & & \\
\hline Lontra longicaudis & & & & & & $\mathrm{x}$ & & & & & & & & & \\
\hline Pteronura brasiliensis & & & & $\mathrm{x}$ & & & $\mathrm{x}$ & & & $\mathrm{x}$ & & & & & \\
\hline Puma concolor & $\mathrm{x}$ & & & & & $\mathrm{x}$ & & & & $\mathrm{x}$ & & & & & \\
\hline Puma yagouaroundi & & & & & & $\mathrm{x}$ & & & & $\mathrm{x}$ & & & & & \\
\hline Leopardus pardalis & & & & & & $\mathrm{x}$ & & & & $\mathrm{x}$ & & & & & \\
\hline Leopardus tigrinus & & & & & & $\mathrm{x}$ & & & & $\mathrm{x}$ & & & & $\mathrm{x}$ & \\
\hline Leopardus wiedii & & & & & & $\mathrm{x}$ & & & & & & & & & \\
\hline Leopardus braccatus & $\mathrm{x}$ & & & $\mathrm{x}$ & & & & & & & & & & & \\
\hline Leopardus geoffroyi & $\mathrm{x}$ & & & & & & & & & & & & & & \\
\hline Panthera onca & $\mathrm{x}$ & & & $\mathrm{x}$ & $\mathrm{x}$ & $\mathrm{x}$ & $\mathrm{x}$ & & & $\mathrm{x}$ & & & & & \\
\hline Smilodon populator & & $\mathrm{x}$ & & $\mathrm{x}$ & $\mathrm{x}$ & $\mathrm{x}$ & $\mathrm{x}$ & & $\mathrm{x}$ & $\mathrm{x}$ & $\mathrm{x}$ & & $*$ & $\mathrm{x}$ & \\
\hline
\end{tabular}

SYSTEMATIC PALEONTOLOGY

Class MAMMALIA Linnaeus 1758

Order CARNIVORA Bowdich 1821

Family FELIDAE Fischer 1817

Genus Panthera Oken 1816

Panthera onca (Linnaeus 1758)

(Fig. 1a and 2a; Table I)

New material. UNIRIO-PM 1026, left P4; UNIRIOPM 1031, maxillary bone fragment with left P4; UNIRIO-PM 1027, maxillary bone fragment with P2 and P3; UNIRIO-PM 1053, right C1; UNIRIOPM 1054, left C1; UNIRIO-PM 1028, second I2; UNIRIO-PM 1057, right third I3; UNIRIO-
PM 1029, right I3; UNIRIO-PM 1032, right I3; UNIRIO-PM 1043, right I3; UNIRIO-PM 1025 , left jaw fragment with $\mathrm{p} 3$ and p4; UNIRIO-PM 1055, indeterminate canine; UNIRIO-PM 1056, indeterminate canine; UNIRIO-PM 1047, fragment of jaw without teeth.

Geographic and temporal provenance. "Gruta do Urso" cave (-12,583; -46,516), Lujanian (late Pleistocene - early Holocene).

Fossil record in South America. The first findings of $P$. onca in South America are from the Ensenadan (early to middle Pleistocene) at "Toscas del Río de La Plata", Buenos Aires, Buenos Aires Province (Berman 1994 although discussed by 
Soibelzon et al. 2008). Since then, the species was also recorded to the late Pleistocene to early Holocene of São Raimundo Nonato, Piauí (Faure et al. 1999); Campo Formoso and Ourolândia, Bahia (Lessa et al. 1998); Lagoa Santa, Minas Gerais (Cartelle 1999, Mayer 2011); Alto Ribeira, São Paulo (Ghilardi et al. 2011); Serra da Bodoquena, Mato Grosso do Sul, Brazil (Salles et al. 2006, Perini et al. 2009); La Carolina, Quito, Ecuador (Hoffstetter 1952, Román-Carrión 2012); Talara, Piura, Peru (Seymour 2010); Tarija (Tonni et al. 2009) and Nuagapua, Chaco, Bolivia (Hoffstetter 1968, Coltorti et al. 2012); Sopas Formation, northern Uruguay (Ubilla et al. 2004); San Francisco, Córdoba Province, and Cañada Las Achiras, Entre Ríos, Argentina (Ferrero 2008, Cruz et al. 2012); Quebrada Quereo formation (Labarca and López 2006); Ultima Esperanza, Lava Field, Pali-Aike, and Tierra del Fuego, Chile (Martín et al. 2004, Massone and Prieto 2004, Martín 2008, Canto et al. 2010); Sierra de Perijá, Estado Zulia, Venezuela (Rincón 2006).

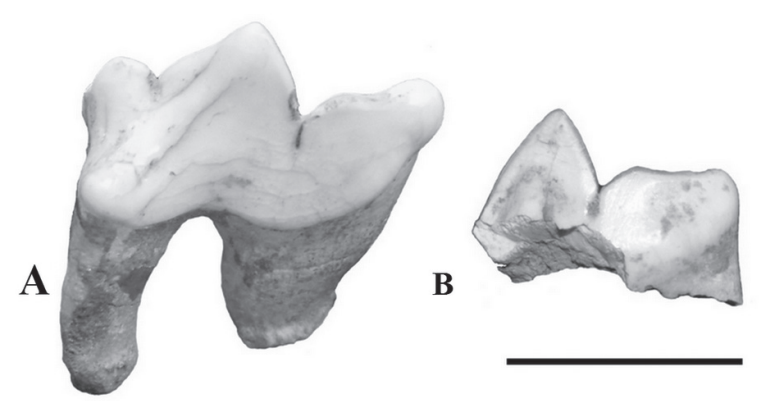

Figure 1 - A- Panthera onca, left P4 in labial view (UNIRIO-PM 1031). Leopardus sp., deciduous P3 in labial view (UNIRIO-PM 1048). Scale $=1 \mathrm{~cm}$.

Description. Upper second incisor (I2) UNIRIO-PM 1028 is well preserved, however, it was not possible to distinguish it as left or right because of the similar morphology between right and left tooth. This tooth is larger than the upper first incisor. The root is mesiodistally compressed along its length. The crown extends laterally forming a triangular form. The labial portion is convex and the lingual portion concave. On the lingual surface of the main cusp there is a deep horizontal groove (where the lower incisor occludes) and a rounded ridge centered at its base.

Upper third incisor (I3) - UNIRIO-PM1029 is a right upper incisor, with little wear on the crown apex, and laterally compressed roots. Both specimens are similar in size, but UNIRIO-PM 1032 is smaller. The right I3 UNIRIO-PM 1043 is the largest specimen among the material. Its crown is much worn with only a small band of enamel left, and the root is slender towards its apex. The tooth is compressed mesiodistally, and resembles a canine for having a conical main cusp. The labial side of the tooth is convex and the lingual side is slightly concave. On the lingual side, there is a narrow enamel crest that extends mesio-distally from the base of the crown to the apex of the main cusp; at this point a cusplet is developed. The distal side is straight and has a small groove where the lower canine occludes.

Upper canine (C) - The upper right canine UNIRIO-PM 1053 has moderate wear on its crown apex. The tooth is also fragmented at several parts of its crown and root. The other tooth, an upper left canine, UNIRIO-PM 1054, presents cracks on the root and on the upper half of the crown.

Maxillary bone - UNIRIO-PM 1027 is a left fragment of maxillary bone bearing the P2 and the P3. The P3 has two main cusps, where the mesial cusp is larger than the distal cusp. At the center of the base of the mesial cusp there is a small cusplet. The distal border of the crown ends with a transverse enamel ridge. The P2 is the smallest upper premolar and it is more developed mesiodistaly than labiolingualy, which forms a round shape. In occlusal view there is an enamel bridge.

Upper fourth premolar (P4) - The left P4 UNIRIO-PM 1031 is well preserved, and has a small fragment of maxillary bone preserved on its labial and lingual portions. The specimen UNIRIO-PM 1026 is 
a left P4, also well preserved, but with some cracks on the root. The tooth has three roots, and the distal one is labio-lingually compressed and comprises the length of the metacone and half of the paracone. The mesiolabial root is positioned below the parastyle, lingually compressed and diagonally positioned. The third root is mesiolingually positioned below the protocone. The apex of this root bends towards the labial side. There are three cusps aligned at the labial border. The mesial cusp, the parastyle, is the smallest; the central cusp, the paracone, is the largest one followed by the distal cusp, the metacone. There is a shearing facet along the apex of all three cusps. The parastyle is conical, and the paracone is taller than the other two cusps being labiolingually compressed. The labial side of the paracone is convex and the lingual is flat. The labial portion of the metacone is also flat. The metacone presents a convex surface on the labial portion. The protocone is the smallest cusp, has round shape, and presents a punctiform projection at the apex which is positioned in front of the junction between the parastyle and the paracone.

Mandible - UNIRIO-PM 1025 is a right fragment of mandible with well preserved $\mathrm{p} 3$ and $\mathrm{p} 4$. The mandible is broken between the distal part of the $\mathrm{p} 4$ and the proximal portion of the mentonian foramen. Both teeth have similar morphology but the $\mathrm{p} 4$ is larger than the p3. On both teeth there is a main cusp which is bigger than the other ones, plus other two accessory cups. The distal accessory cusp is smaller than the mesial one. On both teeth there is also a large cingulum in distal portion.

Indet. canine - UNIRIO-PM 1056 is a well preserved root having only the crown's base. It was not possible to identify this canine as superior or inferior nor right or left. UNIRIO-PM 1055 is a worn root, which was also not possible to identify any further.

Remarks. UNIRIO-PM 1025, 1027, 1031, 1047, 1053, 1054, 1055 and 1056 were all found associated in the sediment. Puma is the most similar taxon to Panthera in size and morphology.
The canines of $P a$. onca are markedly developed and robust. As in Puma concolor, the protocone of the $\mathrm{P} 4$ is placed on the lingual side of the crown (in front of the paracone-metacone boundary), but in $\mathrm{Pa}$. onca the protocone of the $\mathrm{P} 4$ is proportionally larger and much more separated from the other two cusps. Also, the P4's parastyle is larger in $P a$. onca in comparison to $P u$. concolor. The p3 has a much more developed posterior cingulum in $\mathrm{Pa}$. onca. Unlike Pa. onca, the P4 in Pa. leo has a cingulum around the parastyle. The $\mathrm{p} 4$ crown is much lower in $\mathrm{Pa}$. onca than in Pa. leo which has an elongated principal cusp. The parastyle in P4 is less developed in Pa. onca than in Smilodon. In Smilodon all cusps are queued and mesiolabial cusps are absent. The upper canine of Smilodon is clearly broader and longer that the $\mathrm{C} 1$ of $P a$. onca. Moreover, the canines of Smilodon are serrated on its lingual portion and comprised on its mesiodistal portion.

\section{Genus Leopardus Gray 1842}

Leopardus sp.

(Fig. 1b)

New material. UNIRIO-PM 1048, left dP3.

Geographic and temporal provenance. "Gruta do Urso" cave (-12,583; -46,516), Lujanian (late Pleistocene to early Holocene).

Description. Upper fourth premolar (P4) - The left P4 UNIRIO-PM 1048 is broken on the parastyle and protocone and also has missing roots. The paracone is triangular and higher than the metacone. The apex of the metacone is almost straight. The base of the crown in labial view goes up towards the end of the metacone. The labial portion is concave and folds to the inside where the metacone connects the paracone.

Remarks. The specimen is represented by a deciduous tooth. The paracone and metacone are straight on its lingual portion while its cusps are convex in shape. In a permanent tooth, the paracone 

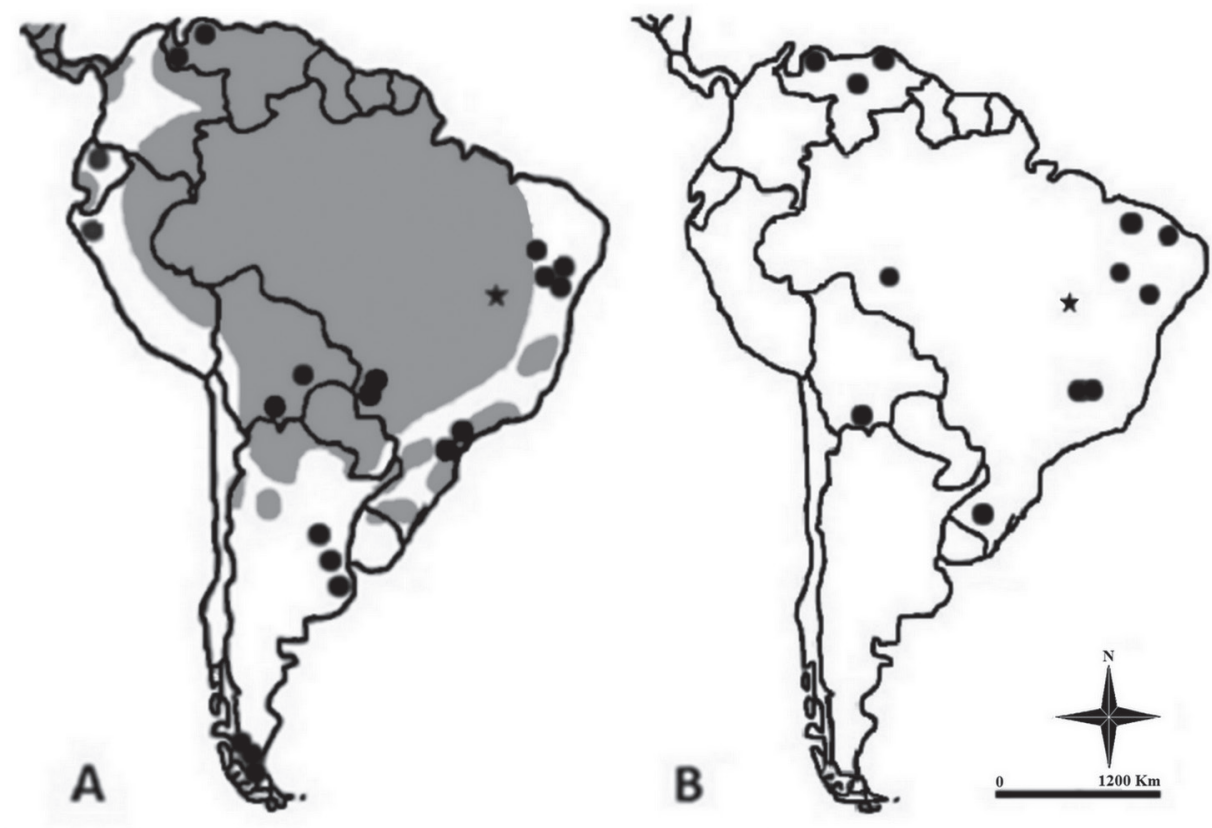

Figure 2 - Maps with the current distributions in South America (in grey; adapted of Wilson and Mittermeier 2009) and fossil record in South America (black dots): A - P. onca (Faure et al. 1999, Lessa et al. 1998, Cartelle 1999, Mayer 2011, Ghilardi et al. 2011, Salles et al. 2006, Perini et al. 2009, Hoffstetter 1952, Román-Carrión 2012, Seymour 2010, Tonni et al. 2009, Hoffstetter 1968, Coltorti et al. 2012, Ubilla et al. 2004, Ferrero 2008, Cruz et al. 2012, Labarca and López 2006, Martín et al. 2004, Massone and Prieto 2004, Martín 2008, Canto et al. 2010, Rincón 2006, Oschenius 1980); B - A. wingei (Paula-Couto 1960, Guérin 1991, Cartelle 1994, 1998, Trajano and Ferrarezzi 1994, Lessa et al.1998, Soibelzon 2002, 2004, 2012, Soibelzon et al. 2005, Ribeiro et al. 2003). ( $\star)$ - Aurora do Tocantins caves.

has a pyramidal form and the cusps are aligned at the labial edge. The deciduous P3 is smaller than in Puma and Panthera. However, the dental morphology of the dP3 is similar to Leopardus pardalis, Leopardus wiedii and Leopardus tigrinus. For that reason the specimen UNIRIO-PM 1048 is identified only by genus level.

\section{Family URSIDAE Fischer 1817}

Genus Arctotherium Bravard 1857

Arctotherium wingei Ameghino 1902

(Fig. 3a and 2b; Table I)

New material. UNIRIO-PM 1033, right I3; UNIRIO-PM 1060, upper incisor indet.; UNIRIO-PM 1021, right C; UNIRIO-PM 1020, left c; UNIRIO-PM 1019, right p1.
Geographic and temporal provenances. "Gruta do Urso" cave $(-12,583$; -46,516) Lujanian (late Pleistocene to early Holocene).

Fossil record in South America. Late Pleistocene of Tarija, Bolivia; Monagas and Muaco, Venezuela (Soibelzon 2004, Soibelzon et al. 2005, Soibelzon and Rincón 2007); Bahia, Brazil (Lessa et al. 1998); Ubajara, Ceará, Brazil (Trajano and Ferrarezzi 1994); São Raimundo Nonato, Piauí, Brazil (Guérin 1991); Rio Grande do Norte, Brazil (Cartelle 1994, 1998); Lagoa Santa, Minas Gerais, Brazil (PaulaCouto 1960); Lapa da Escrivaninha, Prudente de Morais, Minas Gerais, Brazil, (Soibelzon 2002); Rio Grande do Sul, Brazil (Ribeiro et al. 2003).

Description. Upper third incisor (I3) -The right I3 UNIRIO-PM 1033 is well preserved and 


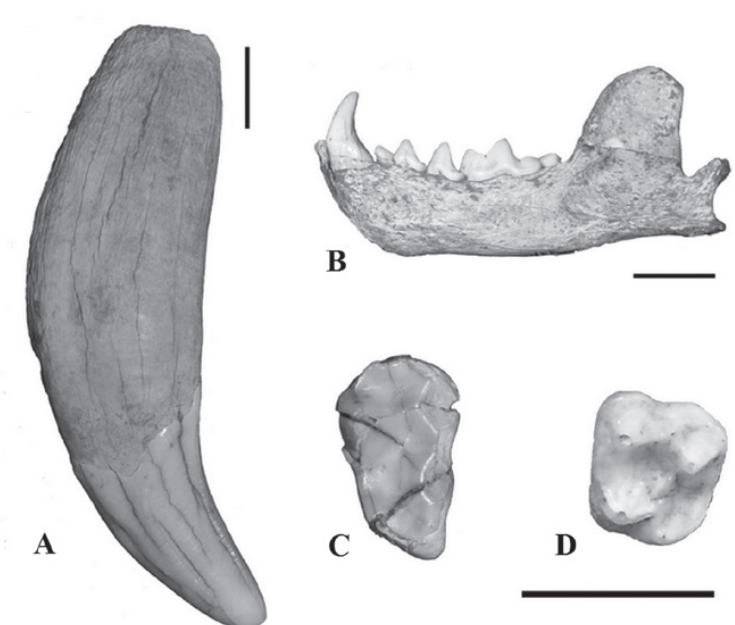

Figure 3 - A- Arctotherium wingei, lower right canine in lingual view (UNIRIO-PM 1020). Galictis cuja, left dentary in labial view (UNIRIO-PM 1007). Procyon cancrivorus, right $\mathrm{m} 2$ in occlusal view. Nasua nasua, left M1 in occlusal view. Scales $=1 \mathrm{~cm}$.

has a deep groove where the tooth occludes with the lower tooth. The tooth is labio-lingually compressed from the root apex to halfway up the crown. The crown has a large central cusp, conically shaped on its base and mesiodistally curved. The crown is convex on labial view, straight on distal view, and concave on mesiolingual view.

Upper incisor indet. - UNIRIO-PM 1060 has the root broken on its apex. The crown is well preserved with little wear. The root is mesiodistally compressed, and larger on the mesial and distal view than on the lingual and labial view. The crown has a triangular form in all views. There is a groove on the occlusal area.

Upper canine (C) - The right canine UNIRIOPM 1021 is well preserved, having few cracks and little wear on the crown. It is a large tooth in both length and width. The crown is conical and slightly labiolingually compressed, and delimited by two enamel crests that are present along the whole length of the crown. The root is long, laterally compressed and gets thinner towards its apex. The mesial part of the root is concave and the distal part is convex.
Lower canine (c) - The left canine UNIRIOPM 1020 is shorter and thinner than its upper correspondent. The crown has little wear and some cracks are present along the whole tooth. The root is bent and longer than the crown. The crown is also bent and has the same crests as the upper canine.

Remarks. All specimens belong to one individual adult specimen. UNIRIO-PM 1020 and UNIRIO-PM 1021 were found associated, and are proportional in size. The occlusion is also perfect between them. A. wingei is the only species known for the late Pleistocene of northern South America (Brazil, Bolivia and Venezuela). The exception is the record of $A$. tarijense to Tarija, Bolivia, in sediments presumed to be younger than early Pleistocene (see Soibelzon et al. 2005, Soibelzon and Rincón 2007). A. wingei is the smallest species of Arctotherium and even though size is not considered a good taxonomic character for bears, the difference between $A$. wingei and the other species is so conspicuous (Soibelzon and Tarantini 2009) that we decided to use it in association with other anatomical characters described in the next segment.

The canines of $A$. wingei are markedly curved labio-lingually. The upper canine is very similar between species of Arctotherium, differing mainly in size. The canine of $A$. wingei is the smallest among the species. The lower canine of $A$. wingei presents two enamel ridges as in $A$. angustidens and A. tarijense, while in $A$. vetustum and $A$. bonariense there are three ridges. The upper third incisor is the largerst incisor of the upper tooth row; it is caniniform, with a high laterally compressed crown. The main cusp is morphologically similar to that of the $\mathrm{I} 2$, the mesial ridge is broader and longer than the distal ridge, and there is no enamel bulge between them. In $A$. vetustum, the distal ridge is very small and the mesial ridge is small, while in A. angustidens and A. tarijense both ridges are large. The total of observed characters leads us to assign the following specimens as $A$. wingei. 
Family MUSTELIDAE Fischer, 1817

Genus Galictis Bell 1826

Galictis cuja (Molina 1782)

(Fig. $3 \mathrm{~b}$ and $4 \mathrm{a}$; Table I)
New material. UNIRIO-PM 1001 is represented by a right and a left dentary. On the right dentary the coronoid and condylar processes are absent. Only the $\mathrm{p} 4$ and $\mathrm{m} 1$ are present, and only the alveoli of
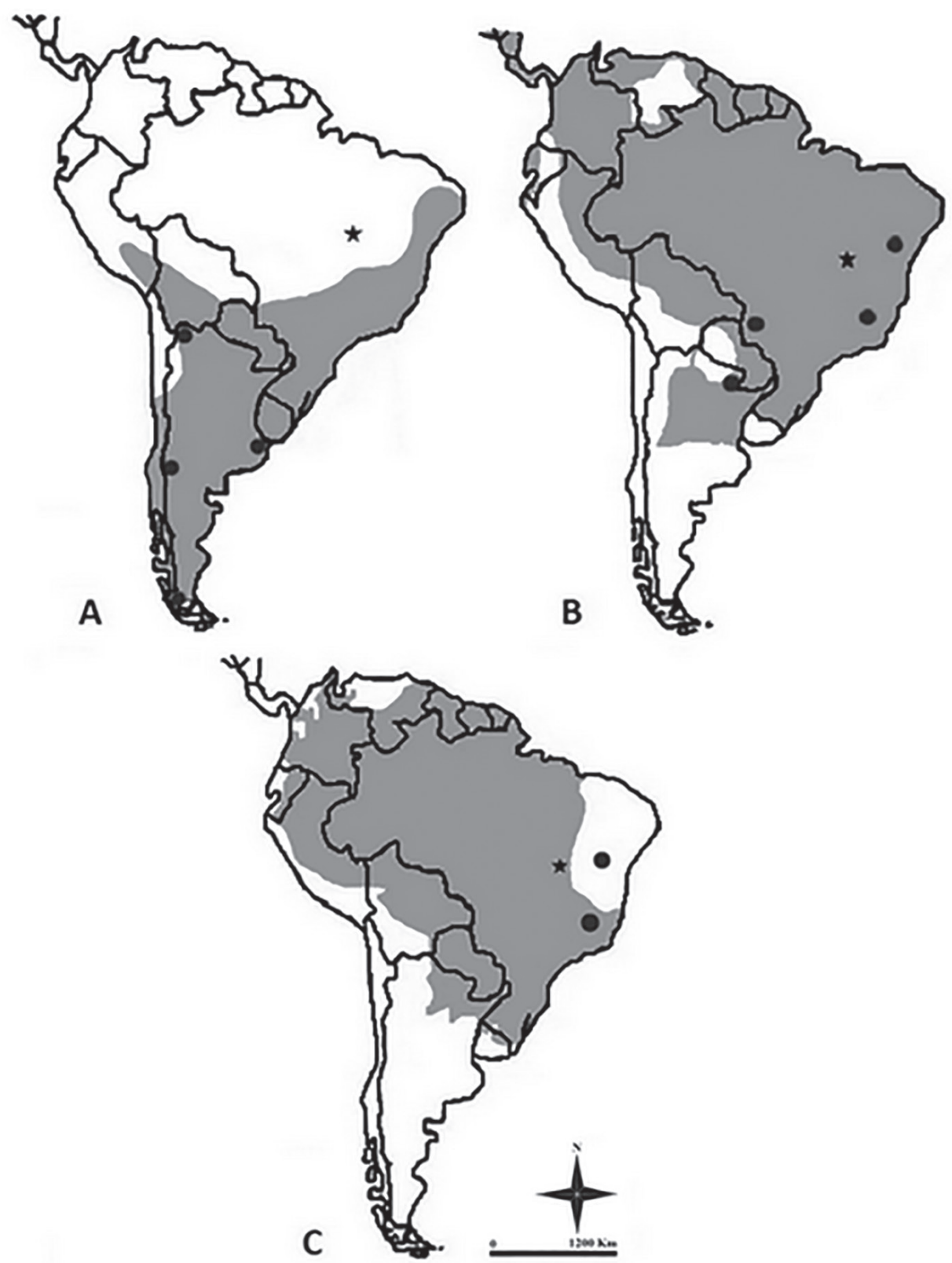

Figure 4 - Maps with current distribution in South America (in grey; adapted from Wilson and Mittermeier 2009) and fossil record in South America (black dots): A - G. cuja (Prevosti in litt, Distel 1986, Mazzanti and Quintana 2001); B - P. cancrivorus (Paula-Couto1970, Lessa et al.1998, Salles et al. 2006, Soibelzon et al. 2010); C - N. nasua (Berta and Marshall 1978, Paula Couto 1970, Cartelle 1999). ( $\star$ ) - Aurora do Tocantins caves. 
the incisors, canine, $\mathrm{p} 3$ and $\mathrm{m} 2$ are preserved. The left dentary has i3, c, p2, p3, p4, m1 and m2 present and no tooth is worn.

Geographic and temporal provenance. "Gruta do Urso" cave $(-12,583 ;-46,516)$, Lujanian (late Pleistocene to early Holocene).

Fossil record in South America. The species is recorded from late Pleistocene to early Holocene of Cueva de Milodón, Magallanes, Chile; Chenque Haichol, Argentina (Massoia 1992); Cueva Tixi, Buenos Aires, Argentina (Mazzanti and Quintana 2001); El Manantial, Provincia Rio Negro, Argentina (Yensen and Tarifa 2003) and Cueva III of Huachichocana, Provincia Jujuy, Argentina (Distel 1986).

Description. Dentaries - UNIRIO-PM 1001 left dentary has its angular process preserved but the coronoid and condylar processes are broken. The labial portion is broken at the same height as the $\mathrm{p} 4$. The material has cracks all over its surface. The mandibular foramen is preserved. The right dentary is broken horizontally at the coronoid process. The fracture was made during the collection of the material, but it was possible to reunite and glue all parts. The angular portion of the condylar process is broken on its lingual portion. Five mentalis foramina and the mandibular foramen are present.

Third lower incisor (i3) - The crown is straight and quadrangular on labial view.

Lower canine (c) - The base of the crown is large and gets thinner towards its apex. The tooth is curved, where the labial portion is convex and the lingual portion is concave.

Third lower premolar (p3) - There is only one conical cusp. A thick cingulum is present in front of the mesial margin of the $\mathrm{p} 4$.

Fourth lower premolar (p4) - This tooth is bigger than the $\mathrm{p} 3$ but it is very similar in form to the $\mathrm{p} 3$. The enamel is elongated behind the single cusp, flexing markedly at the lingual margin of the tooth, while the labial margin is straight. The tooth is placed diagonally on the tooth row.
First lower molar (m1) - The protoconid is straight. There is a thick cingulum at the talonid margin. The metaconid is absent.

Second lower molar (m2) - This molar is smaller than the $\mathrm{m} 1$, subcircular in form and has an enamel crest along the crown. The tooth is placed on the tooth row higher than the other teeth, next to the coronoid process.

Remarks. The genus Galictis is found throughout zoological collections with identifications that have been switched back and forth between $G$. cuja and $G$. vittata. The only dental characteristic that distinguishes G. cuja and G. vittata is the presence of a metaconid on the $\mathrm{m} 1$ of $G$. vittata. Apart from that, both species are very similar, except in size, where G. cuja is smaller than $G$. vittata. Both hemimandibles described here were found at approximately the same place in the cave, but in two different years. These dentaries have similar proportions and their symphyses are well preserved so that they fit together. Therefore, we consider that these dentaries belong to the same individual.

Family PROCYONIDAE Gray 1825

Genus Procyon Storr 1780

Procyon cancrivorus (Cuvier 1798)

(Fig. 3c and 4b; Table I)

New material. UNIRIO-PM 1007, right m2.

Geographic and temporal provenance. "Gruta do Urso" cave (-12,583; -46,516), late Pleistocene to early Holocene.

Fossil record in South America. The species is recorded from late Pleistocene to early Holocene of Argentina (Soibelzon et al. 2010); Lagoa Santa, Minas Gerais, Brazil (Paula-Couto 1970); Bahia, Brazil (Lessa et al. 1998); Serra da Bodoquena, Alto Ribeira, Brazil (Salles et al. 2006).

Description. Lower second molar (m2) - The right m2 UNIRIO-PM 1007 is markedly worn and it probably belonged to an older individual. The mesiodistal length is bigger than the labiolingual length. The distal edge is narrow and triangular. The mesial edge is broad and rounded. The trigonid and 
the talonid have similar dimensions. The metaconid and the hypoconid are absent and it is only possible to identify their bases. The base of the protoconid is almost the same length of the trigonid. The base of the metaconid is about half the size of the base of the protoconid. The base of the hypoconid is similar in length to the base of the protoconid, and is placed behind the mesiodistal portion of the tooth, aligned to the main axis. The entoconid is placed parallel to the mesiodistal portion of the base of the hypoconid. A cristid connects diagonally the base of the hypoconid and the entoconid. The mesial root and part of the enamel on the base of the crown are absent. The material has some cracks on both crown and root.

Remarks. The specimen of Procyon cancrivorus described here represents the first potential late Pleistocene record of the species to Brazil (for more details see Rodriguez et al. 2013).

Genus Nasua Storr 1780

Nasua nasua (Linnaeus 1766)

(Fig. 3d and 4c; Table I)

New material. UNIRIO-PM 1320 left M1.

Geographic and temporal provenance. "Gruta do Urso" cave (-12,583; -46,516), Lujanian (late Pleistocene to early Holocene).

Fossil record in South America. The species is recorded at the late Pleistocene of Tarija, Bolivia (Berta and Marshall 1978); late Pleistocene-Holocene of Minas Gerais, Brazil (Paula Couto 1970) and Bahia, Brazil (Cartelle 1999).

Description. Upper first molar (M1) - Three roots are present: two thin roots on labial position, which are mesiodistally compressed, and one large root of pyramidal form on lingual position. The crown is quadrangular, and longer labiolingually than mesiodistally. There are four cusps of pyramidal form. The paracone is the largest cusp placed at the mesiolabial portion of the crown. This cusp is connected with the metacone and the protocone by a thin enamel crest. The metacone is placed at the distolingual portion of the crown.
Remarks. Usually the M1 has a more rounded outlined crown than the material described here, which has a quadrangular outlined crown. A more rounded outlined crown was also observed in the specimens MNRJ 3075, MNRJ 13518 and MNRJ 32431 housed at the Department of Mammalogy of the Museu Nacional/Universidade Federal do Rio de Janeiro, Brazil. Also, the tooth is worn on the labial portion of the crown. Maybe this wear was caused by friction with upper teeth and/or bad occlusion. Bassaricyon gabbii has only one lingual cusp on the M1. Bassariscus astutus and Bassariscus sumichrasti have differences in form, number of cusps and form of these cusps, and resembles the M1 of Canidae. In Procyon cancrivorus the metacone is more centralized than in Nasua nasua, and presents a large mesiolabial cingulum that is not present in $N$. nasua. On the described material, the M2 is the tooth more similar with Pr. Lotor. However, some differences are recognizable between both taxa, such as lingual cusp larger and more centralized in Pr. lotor than in N. nasua. An other important difference is the presence of two accessory cusps in N. nasua. Also, the M1 of Pr. lotor has a lingual cingulum that is not present in $N$. nasua.

Family CANIDAE Fischer von Waldheim 1817 Canidae indet.

New material. UNIRIO-PM 1321, right mandible fragment with canine.

Geographic and temporal provenance. "Gruta do Urso" cave (-12,583; -46,516); Lujanian (late Pleistocene to early Holocene).

Description. Mandible fragment - UNIRIOPM 1321 is broken behind the mentonian foramen. The mandibular symphysis is long and goes from the incisors to the $\mathrm{p} 2$ alveoli. On the mesial portion of the mandible the alveoli of the incisors are also broken. The canine is the only preserved tooth. Its crown is conical and curved towards the distal portion of the tooth. There are two enamel crests, one on 
the lingual portion and another on the mesial portion, which occludes with the upper third incisive. The crown is fissured perpendicularly to the mandible.

Remarks. The specimen was compared with Lycalopex vetulus, Lycalopex gymnocercus and Cerdocyon thous, due to the dental morphology similarity of these species to our material. The intraspecific variation and similarity of teeth between Canidae taxa have prevented us to identify our specimen beyond family level.

\section{DISCUSSION}

The fossil assemblage of "Gruta do Urso" cave includes the greatest diversity of Pleistocene Carnivora found in association at the same site in South America (Table I). The stratigraphic control applied, assured that all fossils came from the same level. Therefore, this assemblage can be recognized as part of an ancient mammalian community.

Previous studies in Brazilian caves gathered fossil diversity data from a number of caves or merged information from several localities (e.g. Cartelle 1999, Lessa et al. 1998) treating this collection of taxa of different spatial origins as a single ancient ecological community. Moreover, most fossils were found laying over the sediment (out of stratigraphic context), or no stratigraphic control was made during the excavation. In addition, there is also no taphonomic analysis nor numerical dating procedures in those previous studies to assure that all specimens were from the same locality and stratigraphic level. Therefore, these collections might represent artificial assemblages as a result of great temporal and spatial mixture. Although only one dating was performed on the fossils here described, the stratigraphic controlled survey performed at "Gruta do Urso" cave indicates that this assemblage has so far the highest Carnivora diversity for the late Pleistocene of South America.

Nowadays, South America is the continent which has the highest diversity of extant Carnivora
(Van Valkenburgh 1988), but during the Pleistocene this diversity was even greater. Many of the South American extant taxa were already present in the continent during the late Pleistocene, and coexisted with species that became extinct during the late Pleistocene-Holocene boundary (Prevosti and Soibelzon 2012). Therefore, several extant South American carnivores are survivors of the late Pleistocene/Holocene extinctions. The conditions that allowed the survival of those taxa are still unknown, mainly because their fossil records are scarce. However, it appears to be partially related to their medium to small body masses.

Among the extant carnivores which are also recorded to the South American Pleistocene, the best known species from biostratigraphic context and geographic distribution is Panthera onca. Today, $P a$. onca is also the largest living South American carnivore. Yet, large Pleistocene extinct carnivores such as Arctotherium, Smilodon and several taxa of Canidae are also well documented on the fossil record (Soibelzon and Prevosti 2007). The lack of information regarding the fossil record of middle to small-sized Pleistocene Carnivora of South America might lead to the idea of rarity. However, the common usage of survey techniques such as picking that evidence larger fossils (complete or fragmented) may help to support the assumption that smaller carnivore taxa were scarce. Furthermore, this scarcity of middle to small-sized Carnivora in South American Pleistocene deposits can be also a consequence of taphonomic bias (Soibelzon and Prevosti 2007). This would also explain their absence or scarcity in tropical regions (Soibelzon and Prevosti 2007).

Among the Carnivora taxa of Aurora do Tocantins, Arctotherium wingei is the only species that was completely extinct by the late Pleistocene (Soibelzon and Rincón 2007). This is the smallest (Soibelzon and Tartarini 2007) and the most herbivore (Figueirido and Soibelzon 2009) species of Arctotherium. The fossil record presented here represents the first fossil of $A$. wingei from Brazil 
with accurate stratigraphic procedure, since older findings (e.g. the materials from Minas Gerais) were described without stratigraphic context (see Soibelzon et al. 2005).

The described remains of Galictis cuja correspond to the first record of this species to northern Brazil, as well as the first record at lower latitudes of South America. The mustelid G. cuja is currently distributed from southern Peru to Argentina, except for southern Patagonia (Fig. 4a). Nowadays, Galictis cuja inhabits the drier Cerrado (Savanna) and Caatinga (Deserts and Xeric Shrublands) biomes of northeast Brazil, the Atlantic Forest throughout the eastern seaboard, and the pampas grassland towards the south (Bornholdt 2012). Therefore, it is possible that the extinction of G. cuja in northern Brazil was the result of environmental changes occurred during the end of Pleistocene.

The felid Panthera onca, and the procyonids Procyon cancrivorus and Nasua nasua are present today throughout all Brazilian territory, but the fossil records of the last two are more infrequent. These species may inhabit several habitats, such as dry and wet rainforests. They are common in gallery forests and areas close to freshwater, such as swamps, margins of rivers and mangroves (Handley 1976, Schaller 1983, Mondolfi 1986, Emmons 1990). Today, the jaguar $P a$. onca is occasionally found in arid environments, but always nearby water sources (Wilson and Mittermeier 2009). It seems that the ability of $P$. onca to inhabit arid places is not that uncommon, since they occur in arid regions of Mexico and southwestern North America today. Also, late Pleistocene fossil records of jaguars indicate environmental plasticity across much of North and South America. Thus, their current geographic distribution is not necessarily a reflection of their potential range. Other fossils found in "Gruta do Urso" cave are also known for their association to freshwater resources: the sigmodontid rodent Holochilus sciureus (Pardiñas et al. 2011); the boiid snake Eunectes murinus (the anaconda; Hsiou et al. 2013); and the caiman from the subfamily Caimaninae. Although $\mathrm{Pa}$. onca and Pr. cancrivorus currently occur on the studied area, this does not imply that the region was climatically stable since the Pleistocene. Although these species exhibit great environmental plasticity, we can only infer that their presence in the area during the time of deposition indicates freshwater sources nearby the caves.

Hence, the fossil assemblage recovered from "Gruta do Urso" cave indicates that the different climatic conditions and ecosystems might have existed during the late Pleistocene. Those changes probably produced the local extinction of G. cuja and the extinction of $A$. wingei.

\section{ACKNOWLEDGMENTS}

We would like to thank the following curators: João Alves and Sergio Maia Vaz (Museu NacionalUFRJ), Castor Cartelle (Museu PUC-Minas), Marcelo Regueiro (Museo de La Plata), Itati Olivares (Museo de La Plata) and Alejandro Kramartz (Museo Argentino Bernardino Rivadavia) for granting us access to the zoological and paleontological collections. Also, we appreciate all technical and logistic support provided during expeditions by Municipality of Aurora de Tocantins, Mr. Wagner Moura and the Sociedade Brasileira de Espeleologia. The authors also thank Conselho Nacional de Desenvolvimento Científico e Tecnológico (CNPq) (401812/2010-3, Edital $\mathrm{MCT} / \mathrm{CNPq} \mathrm{N}^{\circ} 32 / 2010$ - Fortalecimento da Paleontologia Nacional / Edital 32/2010 - Faixa B and 552975/2011, Apoio a Projetos de Pesquisa / Chamada MCTI/CNPq No 23/2011 - Apoio Técnico para Fortalecimento da Paleontologia Nacional), Fundação Carlos Chagas Filho de Amparo à Pesquisa do Estado do Rio de Janeiro (FAPERJ), Coordenação de Aperfeiçoamento de Pessoal de Nível Superior (CAPES), ANPCyT (PICT 0804), CONICET (PIP 0436) and UNLP (PI 11/N645) for financial support. 


\section{RESUMO}

Os Carnivora terestres do Quaternário brasileiro são representados pelas seguintes famílias: Canidae, Felidae, Ursidae, Procyonidae Mephitidae e Mustelidae. Sua recente história evolutiva na América do Sul está associada com o soerguimento do Istmo do Panamá, que possibilitou o Grande Intercâmbio Biótico das Américas (GIBA). Aqui apresentamos novos registros fossilíferos de Carnivora encontrados em uma caverna no município de Aurora do Tocantins, Tocantins, norte do Brasil. A coleta com controle estratigráfico no depósito sedimentar da caverna estudada revelou um nível fossilífero onde os seguintes taxa de Carmivora estão representados: Panthera onca, Leopardus sp., Galictis cuja, Procyon cancrivorus, Nasua nasua e Arctotherium wingei. A datação por Ressonância Eletrônica de Spin indica que essa assembléia foi depositada durante o Último Máximo Glacial (UMG), há pelo menos 22.000 Ma. O furão, G. cuja é atualmente registrado mais longe do sul do continente que o registro apresentado aqui. Isto pode sugerir que o ambiente próximo à caverna era relativamente mais seco durante o UMG, com vegetação mais aberta, e temperaturas mais moderadas que o atual Cerrado Brasileiro.

Palavras-chave: carnivora, registro fossilífero, Pleistoceno, América do Sul.

\section{REFERENCES}

Ameghino F. 1902. Première contribution a la connaisance de la fauna mammalogique des couches à Colpodon. Bol Acad Nac Cienc Cordoba (Argent) 17: 71-140.

ARAÚJO-JÚNIOR H AND PORPINO K. 2011. Assembléias fossilíferas de mamíferos do Quaternário do Estado do Rio Grande do Norte, Nordeste do Brasil: diversidade e aspectos tafonômicos e paleoecológicos. Pesqu Geoc 38(1): 67-83.

Auler AS, Piló LB, Smart PL, Wang X, Neves WA, Cheng H AND Edwards LE. 2003. Cronologia e Processos de Deposição da Megafauna Quaternária em Cavernas Brasileiras. In: Congresso da Associação Brasileira de Estudos do Quaternário-Abequa 9: 28.

BELL T. 1826. Zoological Meeting, minutes of meeting. Zool J 2: 548-554.

BERGQVIST D. 1993. Long-term prophylaxis following orthopaedic surgery. Haemostasis 23(Suppl.): 27-31.

BERMAN WD. 1994. Los carnívoros continentales (Mammalia, Carnivora) del Cenozoico en la provincia de Buenos Aires: Buenos Aires, Argentina. Universidad Nacional de La Plata, 413 p.
Berta A AND MARShall LG. 1978. South American Carnivora. In: WESTFAL F (Ed), Fossilium Catalogus I: Animalia, Pars. La Haya, 125: v. IX, p. 1-48.

BORNHOLDT R. 2012. Revisão do gênero Galictis (Mammalia, Carnivora, Mustelidae) utilizando métodos morfológicos e moleculares. Pontifícia Universidade Católica do Rio Grande do Sul. Programa de PósGraduação em Zoologia.

BowDICH TE. 1821. An analysis of the classifications of the Mammalia for the use of students and travelers. Paris. J Smith, 115 p.

BRAVARD A. 1857. Observaciones geológicas sobre diferentes terrenos de transporte en la hoya del Plata. Buenos Aires. Biblioteca del diario La Prensa.

CAnto J, YÁñEz J AND Rovira J. 2010. Estado actual del conocimiento de los mamíferos fósiles de Chile. Estud Geol 66(2): 255-284.

CARRIÓNRANDLUIS J. 2012. Hallazgo de Megafauna Pleistocénica en el Centro Histórico de Quito. Rev Politéc 30(3): 136-146.

Cartelle C. 1994. Tempo passado. Mamíferos do Pleistoceno em Minas Gerais. Belo Horizonte. Palco, 132 p.

Cartelle C. 1998. Um pequeno urso do Pleistoceno final da Bahia. Acta Geol Leopold 21(46/47): 171-189.

CARTElle C. 1999. Pleistocene Mammals of the Cerrado and Caatinga of Brazil. In: EISENBERG FJ AND REDFORD $\mathrm{KH}$ (Eds), Mammals of the Neotropics: The Central Neotropics 3: 30-33.

CARTElle C AND Hartwig WC. 1996. A new extinct primate among the Pleistocene megafauna of Bahia, Brazil. Proc Natl Acad Sci 93: 6405-6409.

CARTelle C AND HirookA S. 2005. Primeiro registro pleistocênico de Pteronura brasiliensis (Gmelin, 1788) (Carnívora, Mustelidae). Arq Mus Nac 63(3): 595-598.

CiONE AL AND TONNI EP. 1999. Bioestratigraphy and chronological scale of uppermost Cenozoic in the Pampean Area, Argentina. In: RABASSA J AND SALEMME M (Eds), Quaternary Vertebrate Paleontology in South America, Quatern South Americ Antarc Peninsul, p. 23-51.

Coltorti M, Della Fazia J, Paredes RiOS F AND Tito G. 2012. Nuagapua (Chaco, Bolivia): Evidence for the latest occurrence of megafauna in association with human remains in South America. J South Americ Earth Scienc 33(1): 56-67.

Cruz LE, Fernicola JC, CARignano CA AND Susana BARGO M. 2012. Faunal Assemblages From the Quaternary of San Francisco, Cordoba Province, Argentina. Biostratigraphic and Taxonomic Implications. Ameghiniana 49(4): 642-656.

CUVIER G. 1798. Tableau Élémentaire de l'Histoire Naturelle des Animaux: Paris, Baudouin, 710 p.

DisTEL FAA. 1986. Las cuevas Huachichocana, su posición del precerámico con agricultura incipiente del Noroeste Argentino. Beiträge zur Allgemeinen und Vergleichenden Archäologie 8: 353-430.

EMMONS LH. 1990. Neotropical rainforest mammals: a field guide. University of Chicago Press, Chicago. 
FAURe M, GuÉRIN C AND PARENTI F. 1999. Découverte d'une mégafaune holocène à la Toca do Serrote do Artur (aire archéologique de São Raimundo Nonato, Piauî, Brésil): A gruta do Serrote do Artur (área arqueológica de São Raimundo Nonato, Piaúi, Brasil): datações holocênicas para megafáuna de mamíferos. CR Acad Sci Paris 329(6): 443-448.

FERRERO BS. 2008. Primer registro de Panthera onca Linnaeus 1758 (Carnivora: Felidae) en el Pleistoceno tardío de la provincia de Entre Ríos, Argentina. Temas de la Biodiversidad del Litoral Fluvial Argentino 3: 31.

FIGUEIRIDO B AND SOIBELZON LH. 2009. Inferring palaeoecology in extinct tremarctine bears (Carnivora, Ursidae) using geometric morphometrics. Lethaia.

FISCHER WG. 1817. Adversaria Zoologica. Mém Soc Imp Natl (Moscow) 5: 368-428.

Ghilardi AM, Fernandes MA AND BIRChuetTe ME. 2011. Megafauna from the Late Pleistocene-Holocene deposits of the Upper Ribeira karst área, southeast Brazil. Quatern Int. 245: 369-378.

GoMIDE SMM. 1989. Mamíferos pleistocênicos de Itapipoca, Ceará, Brasil, depositados no Museu Nacional. Dissertação de Mestrado. Museu Nacional da UFRJ, Rio de Janeiro, 172 p. (Unpublished).

GOMIDE SMM, BERGQVIST LP AND DIAS-RÊGO D. 1987. O "tigre dente de sabre” (Smilodon populator) de Itapipoca, Ceará. Congresso Brasileiro de Paleontologia, 10. Anais, p. 197-204.

GRAY JE. 1825. Outline of an attempt at the disposition of the Mammalia into tribes and families with a list of genera apparently appertaining to each tribe. Ann Phil 10: 337-344.

GRAY JE. 1842. Descriptions of some new genera and fifty unrecorded species of Mammalia. Ann Mag Nat Hist, Series $110: 255-267$.

GUÉRIN C. 1991. La faune de vertébrés du pléistocène supérieur de l'aire archéologique de São Raimundo Nonato (Piaui, Brésil). CR Acad Sci Paris, t. 212, Série II, p. 567-572.

HANDLEY CS. 1976. Mammal of the Smithsonian Venezuelan Project. Brigham Young University Science Bulletin, Biological Series, Provo 20: 1-91.

HOFFSTETTER R. 1952. Les mammifêres pléistocênes de la République de I'quateur. Mém Soc déolog. FI'. (n.s.) 21(14): 1-391, pls. I-VII.

HoffstetTer R. 1968. Ñuapua, un gisement de vertébrés pléistocènes dans le Chaco Bolivien. Bul Mus Nat Hist Nat, 2 série 40(4): 823-836.

HSIOU AS, Winck GR, SCHUBERT BW AND Ávilla L. 2013. On the presence of Eunectes murinus (Squamata, Serpentes) from the late Pleistocene of northern Brazil. Rev Bras Paleonto 16(1): 77-82.

LABARCA R AND LÓPEZ P. 2006. Los mamíferos finipleistocénicos de la Formación Quebrada Quereo: (IV Región-Chile): biogeografía, bioestratigrafía e inferencias paleoambientales. Mastozool Neotrop 13(1): 89-101.

Lessa G, CARTelle C, Faria FD and Golçaves PR. 1998. Novos achados de mamíferos carnívoros do Pleistoceno final-Holoceno em grutas calcárias do estado da Bahia. Acta Geol Leopold 21(46/47): 157-169.
LINNAEUS C. 1758. Systema Naturae per Regna Tria Naturae, Secundum Classis, Ordines, Genera, Species cum Characteribus, Differentiis, Synonymis, Locis. Laurentii Salvii, Stockholm 1(10): 824.

LiNNAEUS CV. 1766. Systema Naturae. Editio Duodecima, Reformata. Impensis Direct Laurentii Salvii, Holmiae 1: 1-532.

MARCHESOTTI APA. 2011. Peter Wilhelm Lund: o naturalista que revelou ao mundo a pré-história brasileira. Editora E-papers.

MARTín FM. 2008. Tafonomía y paleoecología de la transición Pleistoceno-Holoceno en Fuego-Patagonia (Doctoral dissertation, Facultad de Ciencias Naturales y Museo).

Martín FM, Prieto A, Roma NMS, Morello F, Prevosti F, CARdenas P AND Borrero L. 2004. Late Pleistocene megafauna at Cueva del Puma, Pali-Aike lava field, Chile. Curr Res Pleist 21: 101-103.

Massoia E. 1992. Arqueología de los Pinares Cordilleranos de Neuquén, II. La Cueva de Haichol. Zooarqueología, I. Mammalia. An Arqueol Etnol, p. 43-45.

MASSONE M AND PRIETO A. 2004. Evaluación de la modalidad cultural Fell 1 en Magallanes. Chungará (Arica) 36: 303-315.

MAYER EL. 2011. Processos de formação de um depósito fossilífero em abismo na gruta Cuvieri (MG): taxonomia, tafonomia e distribuição espacial de fósseis de mamíferos do Pleistoceno (Doctoral dissertation, Universidade de São Paulo).

MAZZANTI DLAND QUINTANACA. 2001. Cueva Tixi: cazadores y recolectores de las Sierras de Tandilia Oriental. Geología, paleontología y zooarqueología. Publicación Especial. Laboratorio de Arqueología, Universidad Nacional de Mar del Plata, La Plata, Argentina.

MolinA GI. 1782. Saggio sulla storia naturale de Chili. Nella Stamperia di S. Tommaso d'Aquino, Bologna, Italy.

Mondolfi E. 1986. Notes on the biology and status of the small wild cats in Venezuela, p.125-146. In: MILLER SD AND EVERET DD (Eds), Cats of the world: biology, conservation, and management. Washington, National Wildlife Federation, $501 \mathrm{p}$.

MoreIRA LEAND MELo SM. 1971. Mamíferos fósseis em Goiás e Distrito Federal. An Acad Bras Cienc 43(Supl.): 553-555.

OCHSENIUS C. 1980. Cuaternario en Venezuela. Introducción a la Paleocología en el Norte de Sudamérica. Cuadernos Falconianos. Ediciones UNEFM, Coro, 69 p.

OKEN L. 1816. Lehrbuch der Naturgeschichte. Thiel 3. Zoologie. C. H. Reclam, Leipzig 2: 1-1270.

PARdiñas UFJ, TETA P, D’Elía G AND LeSSA EP. 2011. The evolutionary history of sigmodontine rodents in Patagonia and Tierra del Fuego. Biol J Linn Soc 103: 495-513.

Paula-Couto C. 1955. O "tigre-dente-de-sabre" do Brasil. Bol Cons Nac Pesq 1:1-30.

Paula-Couto C. 1960. Um urso extinto do Brasil. Bol Soc Bras Geol 9(1): 5-27.

Paula-Couto C. 1970. Paleontologia da região de Lagoa Santa, Minas Gerais, Brasil: Bol Mus Hist Nat 1: 1-21.

PAUlA-COUTO C. 1980. Pleistocene mammals from Minas Gerais and Bahia, Brazil. In: Congreso Argentino de Paleontologia y Bioestratigrafia e Congreso Latinoamericano de Paleontologia, II e 1, Buenos Aires, 1980. Actas Buenos Aires 3: 193-209. 
Perini FA, Guedes PG, Moraes CRN, Fracasso MPA, CARdoso KB, DuHÁ D AND SAlles L. 2009. Carnivores (Mammalia, Carnivora) From The Quaternary Mammals of Serra da Bodoquena, Mato Grosso do Sul, Brazil. Arq Mus Nac, Rio de Janeiro 67(1-2): 119-128.

PORPINO KO, SANTOS MFF AND BERGQVIST LP. 2004. Registros de mamíferos fósseis no Lajedo de Soledade, Apodi, Rio Grande do Norte, Brasil. Rev Bras Paleo 7(3): 349-358.

Prevosti F AND Soibelzon LH. 2012. Evolution of the South American carnivores (Mammalia, Carnivora): a paleontological perspective, Capitulo 6. In: PATTERSON BD AND COSTA YLP (Eds), Bones, clones, and biomes: an 80-million year history of modern Neotropical mammals, University of Chicago Press, p. 102-122.

RANZI A. 2000. Paleoecologia da Amazônia: Megafauna do Pleistoceno. Florianópolis: Editora da UFSC/UFA, 101p.

Ribeiro AM, Rodrigues PH AND Ferigolo J. 2003. Primeiro registro de Ursidae (Tremarctinae) para o Pleistoceno do Estado do Rio Grande do Sul, Brasil. In: Jornadas Argentinas de Paleontologia de Vertebrados, 19, 2003. Resúmenes, Buenos Aires, p. 27.

Rincón A. 2006. Primer registro de jaguar (Panthera onca) en estado fósil para la Sierra de Perijá, Estado Zulia Venezuela. El Guácharo.

RodRIGUES PH, PREVOSTI FJ, FERIGOLO J AND RIBEIRO AM. 2004. Novos materiais de Carnivora para o Pleistoceno do estado do Rio Grande do Sul, Brasil. Rev Bras Paleo 7(1): 77-86.

Rodriguez SG, SoIBELzon LH, Rodrigues S, Morgand CC, BERNARDES C, AVILLA L AND LYNCH E. 2013. First record of Procyon cancrivorus (G. Cuvier, 1798) (Carnivora, Procyonidae) in stratigraphic context in the Late Pleistocene of Brazil. J South Amer Earth Sci 45: 1-5.

SALLES LS ET AL. 1999. Fauna de Mamíferos do Quaternário de Serra da Mesa (Goiás, Brasil). Public Avul Mus Nac 78: 1-15.

Salles L, Cartelle C, Guedes PG, Boggiani PC, Janoo A, Claudis AM AND Russo CAM. 2006. Quaternary Mammals from Serra da Bodoquena, Mato Grosso do Sul, Brazil. Bol Mus Nac Zoologia, 521 p.

SCHALlER GB. 1983. Mammals and their biomass on a Brazilian ranch. Arq Zool 31(1): 1-36.

SEYMOUR K. 2010. The late Pleistocene fossil vertebrates from the Talara tar seeps, Peru, and Corralito, Ecuador, with particular reference to the Carnivora. In: X Congreso Argentino de Paleontología y Bioestratigrafía-VII Congreso Latinoamericano de Paleontología.

SEYMOUR KL. 1989. Panthera onca. Mamm Spec, p. 1-9.

SoIBELzon LH. 2002. Los Ursidae (Carnivora, Fissipedia) fósiles de la Republica Argentina. Aspectos sistemáticos y paleoecológicos. PhD Thesis, Universidad Nacional de La Plata.

SoIBELZON LH. 2004. Revisión sistemática de los Tremarctinae (Carnivora, Ursidae) fósiles de América del Sur. Rev Mus Argent Cienc Nat 6: 105-131.
Solbelzon LH AND PREVosti FJ. 2007. Los carnívoros (Carnivora, Mammalia) terrestres del Cuaternário de América del Sur. 50 Mon. Societat D'Història Natural de Les Balears. Homenatge a Joan Cuerda Barceló.

SOIBELZON LH AND RINCÓN A. 2007. The fossil record of the short-faced bears (Ursidae, Tremarctinae) from Venezuela. Systematic, biogeographic, and Paleoecological implications. Neues Jahrb Geol Palaeontol Abh 245: 287-298.

SOIBELZON LH, ROMERO MRD, AGUILAR H AND TARTARINI VB. 2008. A Blancan (Pliocene) short-faced bear from El Salvador and its implications for Tremarctinaes in South America. Stuttgart. Neues Jahrb Geol Palaeontol Abh 250: $1-8$.

SOIBELZON LH AND TARANTINI VB. 2009. Estimación de la masa corporal de las especies de osos fósiles y actuales (Ursidae, Tremarctinae) de América del Sur. Rev Mus Arg Cienc Nat 11(2): 243-254.

SolBelzon LH, Tonni EP AND Bond M. 2005. The fóssil record of South American short-faced bears (Ursidae, Tremarctinae). J South Americ Earth Sci, p. 105-113.

Solbelzon LH, Zurita AE, Morgan CC, Rodríguez S, Gasparin GM, SoIBElzon E, SChUBERT BW AND MiÑoBoIlini AR. 2010. Primer registro fósil de Procyon cancrivorus (G. Cuvier 1798) (Carnivora, Procyonidae) en la Argentina. Rev Mex Cienc Geol 27(): 313-319.

STORR GCC. 1780. Prodromus methodi mammalium: Tübingen, Litteris Reissianis, 43 p.

Tonni EP, Solbelzon E, CiOne AL, CARlini AA, YANÉ GJS, ZURITA AE AND RÍOS FP. 2009. Preliminar correlation of the Pleistocene sequences of the Tarija valley (Bolivia) with the Pampean chronological standard. Quatern Int 210: 57-65.

Trajano E AND FerrarezzI H. 1994. A fossil bear from Northeastern Brazil with a phylogenetic analysis of the South American extinct Tremarctinae (Ursidae). J Vert Paleontol 55(3): 456-459.

Ubilla M, Perea D, Aguilar CG and Lorenzo N. 2004. Late Pleistocene vertebrate from northern Uruguay: tools for biostratigraphic, climatic and environmental reconstruction. Quatern Int 114: 129-142.

VAN VALKENBURGH B. 1988. Trophic diversity in past and present guilds of large predatory mammals. Paleobiology 14(2): 155-173.

WiLSON DE AND MitTERMEIER RA. 2009. Handbook of the mammals of the world, vol.1. Carnivores. Lynx Ediciones, Barcelona, Spain.

Yensen E AND TARIFA T. 2003. Galictis cuja. Mamm Spec 728: $1-8$. 
